Dobrochna Dabert

Instytut Filologii Polskiej, Uniwersytet im. Adama Mickiewicza w Poznaniu

\title{
Alternatywy wobec jednowymiarowości. Fenomen polskiej kultury niezależnej w PRL
}

W 1977 roku na Biennale w Wenecji, tradycyjnie odnotowującym najnowsze tendencje w sztuce światowej, część wystawy poświęcona została ruchom niezależnym i dysydenckim w komunistycznej części Europy. Staraniem koR-owców zaprezentowano polską ekspozycję zatytułowaną Fasada i tyły. Znalazły się na niej m.in. druki podziemne i zdjęcia z obchodów żałobnych po śmierci Stanisława Pyjasa [zob. Paczkowski 1995: 449]. Wystawie towarzyszyła sesja naukowa, na której Stanisław Barańczak przedstawił referat objaśniający sens, znaczenie i formę rodzącej się kultury niezależnej w Polsce. Pisał m.in.:

Fasada oficjalnej kultury zasłania spory budyneczek kultury nieoficjalnej, zbudowany całkiem solidnie, choć oczywiście w stylu jaskrawo odmiennym niż fasada i nie tak jak ona jednolitym. Większość pomieszczeń tego budynku na tyłach stanowią zresztą podziemne katakumby, które tym bardziej nie rzucają się w oczy zewnętrznemu obserwatorowi. [Barańczak 1981: 254] 
Przeciwstawienie kultury oficjalnej kulturze niezależnej, radykalne oddzielenie fasady od tyłu upraszczało nieco stan faktyczny, choć zrozumiałe było z retoryczno-perswazyjnego punktu widzenia. Pobudzająca wyobraźnię metafora architektoniczna na długo ugruntowała wyobrażenie o zjawisku, z którym mieliśmy do czynienia od połowy lat 70. aż do odzyskania niepodległości. Niemniej już pod koniec 1980 roku na łamach oficjalnej prasy przetoczyła się dyskusja zainicjowana przez Adama Krzemińskiego [1980], który podał w wątpliwość sens podtrzymywania radykalnego podziału w kulturze polskiej'. Nie wszyscy podzielali jego stanowisko. Andrzej Werner [1980] bronił wyrazistego oddzielenia obiegów, wskazując, iż nieoficjalny pełnił funkcję „lekarstwa, podtrzymującego wegetację, szansę życia, nadzieję". Zbigniew Bauer [1980], Piotr Wierzbicki [1980], Wojciech Sadurski [1980], Elżbieta Morawiec [1980] dowodzili, iż odejście od stanu rozdwojenia kultury, jako trwale obecnego od lat, wymaga dłuższego czasu. Do dyskusji włączyli się m.in. Leszek Szaruga, Leszek Bugajski, Janina Zakrzewska i Aleksander Ziemny [Bugajski 1980; Szaruga 1980; Zakrzewska 1980; Ziemny 1980; zob. Czapliński 2006]. Po wprowadzeniu stanu wojennego nowo ukonstytuowana Tymczasowa Komisja Koordynacyjna NSZZ „Solidarność” opublikowała dokument programowy zatytułowany Społeczeństwo podziemne [zob. Wstępne założenia deklaracji... 2010], w którym pobrzmiewały echa dyskusji prowadzonej zaledwie kilka miesięcy wcześniej. Zaproponowana koncepcja Społeczeństwa Podziemnego zamiast Państwa Podziemnego, idei forsowanej m.in. przez Jacka Kuronia, stawiała nacisk na budowanie społeczeństwa samorządowego, organizację niezależnego obiegu informacji, aktywności wydawniczej i samokształceniowej. Zachęcano w niej do zakładania fundacji społecznych, organizowania klubów dyskusyjnych itp. Działalność o charakterze „ruchu wspólnoty narodowej zjednoczonej wokół idei «Solidarności»” miała „tworzyć warunki przybliżające ugodę społeczną" [Wstępne zatożenia deklaracji... 2010: 75 i 74]. Chodziło więc nie tyle o zastąpienie oficjalnych struktur instytucjonalnych, 
ile o stworzenie form obronnych przeciwko „dążeniom władz do jej jednostronnego wykorzystywania i instrumentalnego traktowania" [Wstępne założenia deklaracji... 2010: 75]. W jednym z kolejnych oświadczeń bardzo wyraźnie wskazano na konieczność uczestnictwa w strukturach kultury oficjalnej: „[... ] można i należy korzystać z możliwości prowadzenia niezależnej działalności w tych instytucjach oficjalnych, których celem jest zaspokojenie autentycznych potrzeb społecznych" [Oświadczenie programowe... 2010]. Stanowisko władz podziemnej „Solidarności” wywołało różne reakcje, zarówno aprobujące, jak i polemiczne ${ }^{2}$. Wiktor Kulerski, członek RKW NSzZ „Solidarność” Region Mazowsze, potwierdził ten sposób myślenia o kulturze niezależnej:

W podziemiu kryje się tylko część niezależnych struktur i działań, podczas gdy inne pozostają jawne lub półjawne. Niezależność jest możliwa tylko w niektórych dziedzinach życia społecznego i nie może być atrybutem całości. [Kulerski 2018: 745]

Współczesna refleksja nad zjawiskiem niejednolitej kultury polskiej w schyłkowych dekadach PRL, prowadzona z dłuższego dystansu czasowego, pozwala dostrzec jej wewnętrzne skomplikowane relacje, pola wspólne, rozdzielne i obszary przenikania. Teza Barańczaka o „podwójności” kultury, o głębokim przedziale „między tym, co oficjalne, sztuczne i zuniformizowane, a tym, co nieoficjalne, autentyczne i wewnętrznie wielorakie”, między kulturą „zniewoloną” a „wolną” [Barańczak 1981: 255], z dzisiejszej perspektywy wydaje się uproszczona. Czy rzeczywiście mieliśmy do czynienia z „nową alternatywą, która wymagała dokonywania radykalnych wyborów? Manifest kultury niezależnej Barańczaka: „zamiast «kompromis albo milczenie» powiadamy dziś «kompromis albo niezależność», «kompromis albo autentyczność»,

2 Problem dyskusji i polemik w środowisku literackim na ten temat, publikowanych na łamach podziemnej prasy, podjęłam w pracy Między wizją a spetnieniem. Profile ideowe i artystyczne czasopism literackich $w$ drugim obiegu wydawniczym 1982-1989 [Dabert 2014] - zob. rozdział Wizje demokratycznej kultury w literackich pismach drugiego obiegu. 
«kompromis albo wolność»” [Barańczak 1979: 259] powstał u progu rodzącego się drugiego obiegu. Siłą rzeczy miał on bardziej charakter postulatywny niż diagnozujący stan rzeczy. Sytuowanie zjawisk kulturalnych i artystycznych na dwóch przeciwstawnych biegunach, jak chciał Barańczak, okazało się wątpliwe. Zapytajmy zatem: na czym polegał fenomen kultury niezależnej w kontekście kultury oficjalnej? Tak zarysowany biało-czarny obraz nie uwzględniał różnorodnych odcieni zjawiska. Poza tym układ ten nie był stabilny. Wraz ze zmieniającą się sytuacją polityczną, społeczną i technologiczną ulegał przeobrażeniom. W miarę narastania rozlicznych form oporu społecznego rosły też wpływy i zasięg kultury niezależnej, a kontrola państwowa słabła. Niemniej to nie kultura poza cenzurą zadecydowała o ostatecznym kształcie kultury niezależnej w ostatnich dekadach PRL. Kiedy próbujemy zarysować model funkcjonowania kultury w warunkach państwowego dyktatu, powinniśmy zwrócić uwagę na jej niejednorodność wynikającą z uwarunkowań sytuacyjnych i ideologicznych. Podobne zjawisko występowało w krajach obozu socjalistycznego przy uwzględnieniu różnic spowodowanych odmiennymi tradycjami społecznymi, politycznymi i mentalnościowymi. W każdym z krajów bloku wschodniego inaczej układały się proporcje między kulturą zdominowaną przez jedyny ośrodek polityczny a tą wolną od nacisków. Stąd zaproponowany poniżej model układu nurtów kulturowych odnosi się wyłącznie do Polski³.

Kulturę oficjalną rozumiemy tutaj jako znajdującą się pod kuratelą finansową państwa i przezeń cenzurowaną (prewencyjnie i represyjnie). W ramach kultury oficjalnej możemy wyróżnić odmienne jej nurty, które zostaną tu pokrótce omówione.

Kultura uzależniona konsekwentnie wypełniała zalecenia ideologiczne partii i wspierała system władzy poprzez realizację doraźnie dookreślanej polityki kulturalnej. W tym obszarze sytuowała się prasa polityczna i społeczna, publicystyka, część literatury popularnonaukowej (historycznej i politycznej), cie-

3 Wskazane w tekście egzemplifikacje zjawisk z obszaru kultury wysokiej i popularnej posłużyć mają zobrazowaniu specyfiki wydzielonych kategorii, nie prezentują więc ich pełnej listy. 
szące się szczególnym zainteresowaniem władz formy aktywności kultury popularnej, takie jak festiwale piosenki radzieckiej w Zielonej Górze czy piosenki żołnierskiej w Kołobrzegu [zob. Bittner 2017], choć zdarzały się przypadki wyłamywania się z narzuconych regut ${ }^{4}$. Państwowe zespoły folklorystyczne, otoczone opieką i hołubione przez władze, stanowiły obowiązkową oprawę corocznych ogólnopolskich dożynek, w których uczestniczyli przedstawiciele najwyższych władz partyjnych. Szczególną rolę w legitymizowaniu narzuconego porządku pojałtańskiego odgrywały coroczne widowiska okolicznościowe związane z rewolucją październikową i ze świętami państwowymi, np. 22 lipca czy 9 maja. Do kultury medialnej można zaliczyć wszelkiego rodzaju przeglądy filmowe o nastawieniu propagandowym, np. regularnie organizowane dni filmu radzieckiego, przeglądy filmów z bloku krajów socjalistycznych, również niektóre seriale telewizyjnes ${ }^{5}$. Funkcję jawnego instrumentu propagandowego PRL w latach 1944-1989 pełniła Polska Kronika Filmowa 6 . Bez wewnętrznego dyskomfortu w obrębie kultury uzależnionej działali również pisarze, którzy oferowali literaturę zgodną z oczekiwaniami władz. Jerzy Eisler w ten sposób komentował ich rolę i znaczenie w ówczesnym systemie:

Mam tu na myśli takie wydarzenia, jak: występ w 1967 roku na festiwalu w Sopocie Czesława Niemena, prezentującego swoją kompozycję Dziwny jest ten świat, którą określono potem jako pierwszy polski protest song, czy wykonanie przez Jerzego Stuhra na festiwalu w Opolu w 1977 roku „antypiosenki” Śpiewać każdy może, w której ośmieszył tandetę festiwalowych występów.

W zalecenia kulturalne władz całościowo wpisywały się produkcje: o7 zgłoś się Krzysztofa Szmagiera (1976), serial próbujący godzić zadania perswazyjne z ludycznymi, Życie na goraco (1978) Andrzeja Konica - „sensacyjna wersja propagandy sukcesu” [Szczerba 2015], „produkcyjniak” Dyrektorzy (1975) w reżyserii Zbigniewa Chmielewskiego. Politykę historyczną swoich czasów realizowały seriale dotyczące II wojny światowej: Czterej pancerni i pies (1966-1970) w reżyserii Konrada Nałęckiego i Andrzeja Czekalskiego oraz Stawka większa niż życie (1965-1967) w reżyserii Janusza Morgensterna i Andrzeja Konica.

6 Marek Kosma Cieśliński [2016], autor monografii zatytułowanej Polska Kronika Filmowa. Podgląanie PRL-u, próbuje przekonywać, iż Polska Kronika Filmowa cieszyła się ogromną popularnością i sympatią wśród widzów. Ta zaskakująca teza sprzeczna jest $\mathrm{z}$ doświadczeniem osobistym widzów uczestniczących w kulturze filmowej PRL. 
W czasach Polski Ludowej żartowano gorzko, że aby zostać członkiem Związku Literatów Polskich, trzeba było wydać dwie książki albo... dwóch kolegów. Ten ponury żart nie wziął się przecież z niczego. Mieliśmy wówczas pisarzy, których dorobek artystyczny był w praktyce żaden, a którzy byli doskonale notowani na salonach ówczesnej władzy. Pojęcie grafomanii - w odniesieniu do takich ludzi jak Władysław Machejek, Józef Ozga-Michalski czy Mieczysław Róg-Świostek - jest jak najbardziej na miejscu. A przecież ich książki były wydawane w dużych nakładach, byly nagradzane i pokazywane jako „osiągnięcia naszej socjalistycznej kultury”. [Eisler, Terlecki 2002]

Zgodnie z polityką oświatową kierownictwa partyjnego także cała edukacja znajdowała się pod ścisłą kontrolą rozbudowanego aparatu nadzoru. Na terenie całego kraju obowiązywały ujednolicone podręczniki i programy nauczania. Szkolnictwo, w całości finansowane przez państwo, nie tylko przekazywało wiedzę, lecz także pełniło istotną funkcję ideologiczną. W szczególności dotyczyło to takich przedmiotów, jak: historia, wstęp do nauk o społeczeństwie, język polski, język rosyjski, a nawet geografia. Wiadomo jednak, że nie wszyscy nauczyciele realizowali nałożone na nich powinności światopoglądowego kształtowania postaw młodzieży. Przykładem, wcale nie jednostkowym, niepokornego nauczyciela, była choćby polonistka Krystyna Starczewska, która pracowała w warszawskich szkołach, zanim została działaczem opozycji, a w wolnej Polsce dyrektorem słynnego Zespołu Społecznych Szkół Ogólnokształcących „Bednarska”. Jan Olaszek w tekście jej poświęconym pisał: „Była nauczycielką niezwykle popularną wśród uczniów. Na prowadzonych przez nią lekcjach polskiego nie było śladu dominującej ideologii; wręcz przeciwnie - dawała ona wyraz swojej krytycznej ocenie PRL". [Olaszek 2017b: 167]. Ocenę historyka potwierdzali jej byli uczniowie, np. twórca największej podziemnej oficyny wydawniczej Mirosław Chojecki, żona generała Jaruzelskiego Barbara, a nawet późniejszy tajny współpracownik SB TW „Józef”.

Nawet więc w monolitycznej kulturze uzależnionej pojawiały się godne odnotowania wyłomy. Z czasem były one tak liczne, że 
od 1956 roku za główny nurt polskiej kultury powojennej można uznać kontrolowaną kulturę umykającą zaleceniom ideologicznym. Funkcjonujący w niej twórcy i odbiorcy wyszukiwali dla siebie rejonów aktywności, które pozostawały poza szczególnym zainteresowaniem władzy. Bywały lekceważone, bo zdaniem decydentów nie posiadały potencjału ideologicznego. Stąd od 1956 roku artyści, którzy działali w obszarze sztuki awangardowej, abstrakcyjnej, jeśli tylko osobistą postawą społeczną czy polityczną nie dawali powodów do podejrzeń o nieprawomyślność, zbytnio nienękani, mogli realizować się twórczo. U progu dziesiątej dekady Jan Błoński tak wyjaśniał stosunek władz do literackiej sztuki eksperymentującej:

[...] władza pojęła, że awangardowe figliki, których oczywiście nie brała poważnie, uważając za pańskie czy żydowskie fanaberie... że więc te igraszki nie tylko nie przynoszą szkody, ale nawet - umiejętnie subsydiowane - mogą odciągnąć młodych a zdolnych od niepotrzebnych opozycji, kontestacji i dysydencji. [Błoński 1990: 12]

Ucieczka w prywatność języka i świata ochroniła też twórczość Mirona Białoszewskiego, którego postawę Barańczak [1974] określił jako umiejętność „bycia sobie jednym”, choć wśród ludzi i razem z nimi. Reżyser Andrzej Kondratiuk znalazł swoją enklawę twórczą $\mathrm{w}$ filmie autorskim $\mathrm{z}$ dala od głównych nurtów rodzimego kina. Polityczni kontrolerzy, lekceważąc eksperymentalną twórczość w dziedzinie filmu animowanego Zbigniewa Rybczyńskiego, Jana Lenicy, Waleriana Borowczyka, Hieronima Neumanna, Jerzego Kuci, Mieczysława Waśkowskiego czy Andrzeja Pawłowskiego, nie przeszkadzali w jej rozwoju. Zdaniem Tadeusza Lubelskiego:

Wolność zdobyta na tym terenie przez filmowców dotyczyła zarówno poszukiwań warsztatowych (w zakresie uproszczonego rysunku, wycinanki, plamy barwnej), jak wymowy politycznej dzieł, (czemu sprzyjała mnogość nagród na zachodnich festiwalach). [Lubelski 2015: 326] 
Z podobnych powodów filmowe animacje dla dzieci realizowane przez Władysława Nehrebeckiego, Lechosława Marszałka, Witolda Giersza czy Adama Kiliana miały szansę zdobyć wysoką pozycję na świecie. Własne strategie ocalenia wolności artystycznej wypracowali tak różni artyści, jak: twórca teatru Cricot-2 Tadeusz Kantor, założyciel Wrocławskiego Teatru Pantomimy Henryk Tomaszewski, reformator teatru XX-wiecznego Jerzy Grotowski czy malarz i rzeźbiarz Zdzisław Beksiński.

Na mniejszą podejrzliwość cenzora mogli liczyć pisarze, którzy wypowiadali się w literaturze przybierającej kostium historyczny czy fantastyczny? $\mathrm{Z}$ tego powodu powieści Antoniego Gołubiewa, Teodora Parnickiego czy Hanny Malewskiej wydawane były bez większych przeszkód. Podobnie rzecz się miała z twórczością Stanisława Lema, która pomimo zastrzeżeń cenzorów obecna była w oficjalnej przestrzeni wydawniczej. Poetyka maski mogła skutecznie chronić przed podejrzliwością władzy. Kontrowersje budziła natomiast twórczość skupiona na poszukiwaniach innowacyjnych rozwiązań formalnych: Andrzeja Kuśniewicza, Leona Gomolickiego czy Leopolda Buczkowskiego, którym Michał Głowiński postawił zarzut o „socparnasim” w artykule z 1981 roku [zob. Głowiński 1981]. Dziesięć lat później złagodził nieco swoje stanowisko w wersji tekstu opublikowanego w zbiorze szkiców. Pisał wtedy:

Przynajmniej niektóre z tych utworów, które skłonni bylibyśmy uznać za reprezentatywne dla socparnasizmu, zachowały wartość, a i samemu zjawisku oddać przystoi to, co się należy. Dzięki niemu zachowała się pewna kultura literacka, nie obniżono poziomu literackiego mówienia, a to już dużo. Sam socparnasizm [...] nigdy nie stał się narzędziem propagandy, zachował niezależność - niestety głównie dlatego, że społecznie niewiele znaczył. [Głowiński 1992]

Sztukę muzyczną przed ingerencjami politycznymi chroniła jej asemantyczność, jeśli tylko kompozytorzy nie wprowadzali zaka-

7 Pisał na ten temat Ryszard Nycz [1998] w tekście Literatura polska w cieniu cenzury: wyktad. 
zanych treści w tytule utworu czy dedykacji lub nie podejmowali działalności opozycyjnej.

W miarę „niezagrożonym” terenem aktywności twórczej była działalność naukowa i specjalistyczna niedotycząca strategicznych politycznie, ideologicznie i gospodarczo dziedzin. Badania nad kulturą antyczną czy średniowiecza były „bezpieczniejsze”, choć nie wszystkie ucieczki, choćby w tematykę historyczną, kończyły się powodzeniem. Po wprowadzeniu stanu wojennego zaostrzona została kontrola publikacji. Andrzej Friszke [2018: 21] wspominał: „Byłem redaktorem działu historycznego $\mathrm{w}$ «Więzi» $\mathrm{i}$ cenzura ingerowała w każdy numer nawet, jeśli tekst dotyczył pierwszej wojny światowej”. Natomiast teoretyk literatury Michał Głowiński, który rozpoczął badania naukowe jeszcze w końcowej fazie czasów stalinowskich, swoją dyscyplinę widział jako częściowo wolną od nacisków politycznych:

Zajmując się teorią literatury, na żadne ograniczenia nie natrafiałem, ta wysoce abstrakcyjna problematyka szczęśliwie przestała interesować strażników komunistycznej ortodoksji. Myślę, że i ja, i moi koledzy umieliśmy tę sytuację wykorzystać. Inaczej oczywiście było, gdy chodzi o historię literatury współczesnej, $\mathrm{w}$ tej dziedzinie ograniczenia istniały, i to duże. Nie miały one postaci niezmiennej, poza trwającym wiele dziesięcioleci zakazem zajmowania się pisarzami żyjącymi na emigracji. W tej dziedzinie starałem się koncentrować na tych sprawach i zjawiskach, o których mogłem pisać swobodnie. [Głowiński 2002: 26-27]

Wprawdzie ograniczenia cenzuralne dotyczyły również kosztownych prac edytorskich, jednak ostatecznie dzieła te okazywały się wartościowym i ponadczasowym dokonaniem ${ }^{8}$. Wyjątkową

8 Można wskazać na tak wielkie przedsięwzięcia edytorskie, bibliograficzne i leksykograficzne, jak powojenną kontynuację (od 1947 roku) serii Biblioteka Narodowa wydawanej przez wrocławskie Ossolineum czy dwie edycje Dziet wszystkich Juliusza Słowackiego. Pierwsza przygotowana przez Towarzystwo im. A. Mickiewicza pod redakcją Juliana Krzyżanowskiego (1949 - 12 tomów) i druga wydana pod auspicjami Zakładu Narodowego im. Ossolińskich pod 
inicjatywą na skalę całego bloku komunistycznego był Klub Krzywego Koła - otwarte forum dyskusyjne skupiające inteligencję o różnorodnych poglądach, ale wykazujące zdecydowany krytycyzm względem władz. Uczestnikami rozmów prowadzonych w Klubie byli tak wybitni intelektualiści, jak: Leszek Kołakowski, Władysław Bartoszewski, Paweł Jasienica, Antoni Słonimski, Jan Strzelecki, Jan Józef Lipski, Stefan Król, którzy debatowali na cotygodniowych spotkaniach z reprezentującymi radykalnie odmienne poglądy Jerzym Urbanem czy Jerzym Braunem. Działalność Klubu Krzywego Koła, związana z odwilżą popaździernikową, została administracyjnie przerwana w 1962 roku'

Krytyk filmowy Tadeusz Sobolewski, uprawiający w PRL twórczość wystawioną na ryzyko szczególnego zainteresowania funkcjonariuszy strzeżących litery polityki kulturalnej, wybrał strategię wyrazistego subiektywizowania swoich wypowiedzi na temat kina. Po latach nazwał ją pisaniem „swoimi słowami”. Ta metoda

dawała pewną autonomię. To nie narcyzm kazał mi, pisząc o filmie, mieszać go $\mathrm{z}$ analizą własnego przeżycia. Domagała się tego sama natura filmu. W tekstach filmowych starałem się racjonalizować przeżycie, które jest podstawą i nieodłącznym warunkiem odbioru. [Sobolewski 2012: 12]

Krzysztof Kościuczuk w pracy poświęconej wystawom plastycznym zorganizowanym w polskich instytucjach kultury w latach 60. i 70. w szczególny sposób skupił się na formach przedsięwzięć realizowanych na polu sztuki oficjalnej, a pozbawionych

redakcją Juliusza Kleinera i Władysława Floryana (1952-1975 - 17 tomów). W latach 1948-1955 trwały prace nad jubileuszowym wydaniem Dziet wszystkich Adama Mickiewicza (16 tomów); 20 tomów Kronik Bolesława Prusa (1956-1970) pod redakcją Zygmunta Szweykowskiego opublikowano w PIw. Bibliografia Literatury Polskiej „Nowy Korbut” ukazywała się od 1963 roku nakładem PIW i Ossolineum; 11-tomowy Stownik Języka Adama Mickiewicza przygotowany był w latach 1962-1983 staraniem Ossolineum. Podczas prac nad wielotomowym Stownikiem Języka Polskiego pod redakcją Witolda Doroszewskiego, wydawanym w latach 1958-1969, pojawiały się trudności spowodowane ingerencjami cenzury [zob. Saloni 1987; Szkiłądź 1997]. 
ideologicznej nadbudowy. Wskazał wydarzenia, które odegrały istotną rolę w polskiej sztuce wystawienniczej:

Metafory kuratorowane przez Ryszarda Stanisławskiego z 1962 r., Romantyzm i romantyczność $w$ sztuce polskiej XIX i XX w. Jacka Waltosia i Marka Rostworowskiego z 1975 r., Widzieć i Rozumieć Mieczysława Porębskiego i Andrzeja Pawłowskiego z 1975 r. oraz Polaków portret wtasny Rostworowskiego z 1979 r. To byly rozmaite formaty wystawiennicze, choć zazwyczaj łączące dzieła historyczne ze sztuką współczesną. Traktuję te wystawy, jako istotne dla praktyki artystycznej w Polsce. [... I I tak w 1962 r. Stanisławski przy pomocy wystawy w pewnym sensie utorowal drogę tak zwanej „sztuce metaforycznej”. Porębski, zapraszając żyjących artystów do stworzenia prac wobec cennych obiektów w krakowskich Sukiennicach w 1975 toku, zaproponował też inne spojrzenie na model działania muzeum. W ogóle z okazji ówczesnego Kongresu Międzynarodowego Stowarzyszenia Krytyków Sztuki (AICA) w Polsce działo się wówczas mnóstwo ciekawych rzeczy. Z kolei dwie wystawy, które tworzył bądź wspóltworzył Rostworowski należą do najważniejszych wydarzeń polskiego życia kulturalnego w ogóle. Stanowią wypowiedź, w której autor znajduje wspólny język $\mathrm{z}$ widzami z różnych warstw społecznych. [Kościuczek 2016]

Warto podkreślić, że ekspozycja Polaków portret wtasny, przygotowana w przeddzień wydarzeń sierpniowych, zakwestionowała propagandowy pogląd, iż Polska narodziła się w 1945 roku, a wydarzenia i osiągnięcia wcześniejsze nie miały większego wpływu na rzeczywistość. Jak po latach przekonywał historyk sztuki Andrzej Szczerski: „Ta dłuższa genealogia - to, że polskość ma długą historię, a współczesna Polska jest kontynuacją tego, co było przed wojną była niezwykle wywrotową tezą" [„Polaków portret własny”... 2018].

Eisler przy okazji refleksji nad kulturą PRL zwrócił uwagę na „nieszczelność” państwowego nadzoru nawet nad telewizją:

Władze komunistyczne dość długo nie doceniały propagandowych możliwości telewizji. Na pewno nie doceniał ich Wła- 
dysław Gomułka i może właśnie dlatego lata sześćdziesiąte to „złoty okres” Teatru Telewizji, Kabaretu Starszych Panów, wielu znakomitych programów satyrycznych, Jana Kociniaka i Jana Kobuszewskiego czy Jacka Fedorowicza i Bogumiła Kobieli. Zapomina się też często o telewizyjnym uniwersytecie dla nauczycieli i o tym, że w telewizji odbywały się pasjonujące dyskusje na wiele ważnych tematów. A wszystko to działo się w okresie funkcjonowania cenzury i dyrektyw plynących z Biura Prasy кc! [Eisler, Terlecki 2002]

W nurtach kultury powojennej, uwzględniając kryterium ograniczonego kręgu odbiorczego, można także wyróżnić oficjalną kulturę niszową, której specyfika pozwalała na względnie dużą swobodę ekspresji artystycznej. Moglibyśmy tu wskazać na przedsięwzięcia kulturalne funkcjonujące przede wszystkim w środowisku inteligenckim. Po 1956 roku w miarę swobodnie rozwijała się sztuka piosenki poetyckiej Marka Grechuty, Wojciecha Młynarskiego, Magdy Umer, Agnieszki Osieckiej i wielu innych. Studencki ruch teatralny, istotny składnik szerszego zjawiska, jakim była kultura studencka, rozkwitł u progu lat 60. (sts, Bim-Bom, krakowski Teatr 38), by w połowie tej dekady skierować się w stronę poszukiwań formalnych (np. Studencki Teatr Pantomimy Gest we Wrocławiu, Gong-2 w Lublinie, Galeria w Gdańsku). Wydarzenia polityczne z lat 1968-1970 oraz docierające do Polski echa zachodnich ruchów kontrkulturowych przeformułowały teatr studencki, czego efektem były dokonania poznańskiego Teatru Ósmego Dnia, krakowskiego Teatru STU, łódzkiego Teatru 77, Sceny Plastycznej KUL w Lublinie czy warszawskiej Akademii Ruchu. Z kolei miejscem prezentacji filmów, które nie mogły znaleźć się na ekranach wielkich kin, oraz swobodnej wymiany opinii były Dyskusyjne Kluby Filmowe, a także kina studyjne.

W ramach kultury oficjalnej usytuowana była także kultura konfrontująca się z ograniczeniami, nieuciekająca od polemiki, sporu z cenzorem i władzą, publicznie odrzucająca podporządkowanie ideologiczne, stawiająca swojej kontrolowanej działalności artystycznej wyraźne granice kompromisu z władzą, stosująca rozliczne gry z cenzurą. Pisarze, których dzieła nie uzyskały aprobaty 
wydawniczej (cenzorskiej), stosowali różne wybiegi stylistyczno-słownikowe w zakwestionowanych passusach. Jeśli to nie pomagało, zmieniali wydawnictwo, a tym samym, przypisanego mu cenzora. W poszczególnych dziedzinach twórczej aktywności wypracowywano rozliczne języki ezopowe, korzystając z długiej, bo sięgającej czasów zaborów, tradycji. Dzięki temu legendarny kabaret literacki Piwnica pod Baranami, pomimo nękania przez tajne służby, prezentował przez caly okres trwania PRL swoje spektakle. Opanowanej sztuce „gry z cenzurą” zawdzięczamy zaistnienie i upublicznienie w warunkach kultury kontrolowanej np. Polskiej Szkoły Dokumentu (tzw. czarna seria), Polskiej Szkoły Filmowej, Kina Moralnego Niepokoju, polskiego dokumentu od lat 6o., również fenomen pojawienia się i rozkwitu polskiego rocka w latach 80 . [Toborek 2010].

Odrębny, wewnętrznie skomplikowany nurt tworzyła koncesjonowana kultura katolicka. Na jednym biegunie sytuowało się środowisko PAX-u, które podjęło współpracę z władzą i popierało jej posunięcia. Pozostając częścią systemu, uczestniczyło w pracach Frontu Jedności Narodu, a potem w Patriotycznym Ruchu Odrodzenia Narodowego. Instytucja ta uzyskała nawet zgodę na utworzenie własnego wydawnictwa i publikowanie kilku tytułów prasowych. Ponadto $\mathrm{w}$ wielu polskich miastach prężnie funkcjonował Klub Inteligencji Katolickiej. Powstał na fali odwilży popaździernikowej i działał za pozwoleniem władzy. KIK miał swoje przedstawicielstwo w sejmie w latach (1957-1976), ale po 1976 roku część z aktywistów Klubu podjęła działalność jawnie opozycyjną i odegrała w kulturze niezależnej lat 70. i 80. niebagatelną rolę. Wśród nich znaleźli się m.in. Tadeusz Mazowiecki, Stefan Kisielewski, Andrzej Bohdan Celiński, Henryk Wujec, Andrzej Wielowieyski.

W ostatnich dekadach systemu szczególne znaczenie miały Tygodnie Kultury Chrześcijańskiej, organizowane cyklicznie od 1975 roku w wielu miastach większych i mniejszych. Charakter tych wydarzeń, zwłaszcza w latach $80 .{ }^{10}$, wykraczał poza stricte reli- 
gijny". Również czasopisma katolickie (np. „Tygodnik Powszechny”, „Znak”, „Więź”, „Przegląd Powszechny”, „W Drodze”) pełniły istotną funkcję kulturotwórczą, oferując wielowymiarową refleksję nakierowaną na chrześcijańskie wartości. Z czasem niektóre z nich skupiać poczęły wokół siebie środowiska opozycyjnie nastawionej inteligencji. Na przykład redakcja „Przeglądu Powszechnego" podczas stanu wojennego była miejscem spotkań opozycji demokratycznej, miesięcznik „W Drodze” publikowal na swoich łamach teksty „niepokornych” autorów, m.in. Anny Kamieńskiej czy Andrzeja Kijowskiego. W 1988 roku nakładem wydawnictwa działającego przy tym miesięczniku ukazała się proza Gustawa Herlinga-Grudzińskiego Wieża i inne opowiadania.

Dopiero po uwzględnieniu kontekstu niejednorodnej kultury oficjalnej można wskazać miejsce kultury nieoficjalnej na ogólnej mapie kultury polskiej. Kultura ta nie poddawała się państwowej kontroli i odrzucała w całości politykę kulturalną. Niefinansowana przez państwo, wspomagana była datkami wspólnoty kontestującej, a także w istotnym stopniu przez ośrodki zagraniczne (państwowe i społeczne) wspierające działania opozycyjne w Polsce. Nastawiona wrogo wobec ideologii państwowej, jawnie deklarowała antykomunizm.

Określający ją termin kultura niezależna wskazuje właśnie na ten rodzaj niezawisłości, bo „niezależną”, w pełnym tego słowa znaczeniu, nie była, bo być nie mogła. Jej kształt modelowany był przez bardzo szeroki program polityczny, społeczny i światopoglądowy środowiska opozycyjnego, a to zobowiązywało związanych z nią twórców do respektowania zróżnicowanych oczekiwań wszystkich uczestników ruchów kontestujących. Dawał również o sobie znać „imperatyw wspólnego głosu” - nakaz podporządkowania wspólnocie swojej indywidualnej, twórczej ekspresji.

Jerzy Urban, osławiony rzecznik prasowy z lat 8o., nie miał złudzeń co do charakteru tego typu przedsięwzięć, skoro współtworzone były przez osoby związane z opozycją albo wręcz opozycjonistów, np. Adama Michnika, Marka Nowakowskiego, Jacka Fedorowicza, Stanisława Tyma i innych. Pisał: „Imprezy tygodnia pokazują, że przez kulturę chrześcijańską pewne środowiska duchowe i świeckie rozumieją nie tylko kulturę inspirowaną treściami i tradycjami religijnymi, lecz w jej obrębie mieści się wszystko, co urąga socjalizmowi” [Rem 1986: 4]. 
Już w czasach „pierwszej Solidarności” pojawiały się pełne autokrytycyzmu głosy dotyczące przyszłości kultury podziemnej i ludzi związanych z opozycją $a^{12}$. W drugim obiegu nie było instytucjonalnej cenzury, ale działali redaktorzy czasopism i oficyn wydawniczych, którzy teksty nie tylko zatwierdzali, ale także poprawiali lub odrzucali. Tak jak w każdym systemie kultury i w każdej epoce nie zanikła też autocenzura korygująca swobodę twórczą. Nierzadko włączenie się do wspólnoty „niezależnych” okupione było w sztuce grzechem doraźności. Literatura, przedstawienia teatralne, muzyka musiały powstawać szybko, bo były potrzebne tu i teraz w momencie „chwili dziejowej”. O konsekwencjach sztuki doraźnej debatowano już w latach 80. na łamach podziemnych czasopism [Dabert 2014].

Nie do przecenienia było wsparcie działań opozycyjnych przez Kościół katolicki. Księża i zakonnicy gremialnie udostępniali salki parafialne, klasztorne korytarze, a nawet kościoły na wystawy, występy artystyczne, prelekcje i projekcje filmowe. W okresie stanu wojennego Kościół pełnił funkcję mecenasa kultury nieoficjalnej. Rodziło to swego rodzaju niepisane zobowiązanie wobec darczyńcy, o czym wielu twórców, szczególnie ze środowiska plastyków i muzyków, mówiło wprost. Konsekwencją było zjawisko dominacji tematyki religijnej i patriotycznej w powstających, prezentowanych i wykonywanych dziełach plastycznych i muzycznych.

Zdaniem krytyczki sztuki Doroty Jareckiej wystawy przykościelne, będące $\mathrm{w}$ „latach osiemdziesiątych alternatywą dla oficjalnego życia artystycznego”, stały się „nieomal synonimem sztuki tej dekady ${ }^{{ }^{13}}$. Najbardziej znanym aranżacjom artystycznym przy-

Owe niepokoje trafnie oddawał utwór Jana Krzysztofa Kelusa Piosenka patetyczna z 1981 roku. Bard śpiewał: „[... ] / Niezależni, samorządni, / od odnowy, do od nowa / nie widzimy, jak nas także / okrążają własne słowa / zasłuchani w własne słowa / coraz bardziej ideowi, / ustąpimy miejsca młodszym, / żeby stworzyć nowy zBowiD" [Kelus 1981].

Aleksandra Ściegienna [2011: 81], podsumowując stanowiska młodych artystów przedstawione w ankiecie Stowarzyszenia Historyków Sztuki, wskazała negatywna ocenę, jaką wystawili artyści mecenatowi Kościoła: „Większość artystów ma już za sobą doświadczenie wystaw przykościelnych, ich cenzurowania przez lokalnych proboszczów, egzaltacji tematów narodowowyzwoleńczych, braku rzeczywistego zainteresowania sztuką". 
gotowywanym przez Janusza Boguckiego i Ninę Smolarz w warszawskich świątyniach: Znak krzyża (1983), Apokalipsa - światło w ciemności (1984), Labirynt - przestrzeń podziemia (1989), jak podkreśla Jarecka, „przyświecała koncepcja wspólnotowych działań” ${ }^{14}$. We Wrocławiu w latach 1984-1989 działała, kierowana przez artystę i krytyka Jana Rybę, Galeria na Ostrowie, mieszcząca się w piwnicach kościoła św. Marcina. Zorganizowano tu ok. 50 wystaw i spotkań. Obok tej inicjatywy, podlegającej strukturalnie i formalnie kurii metropolitalnej, działała grupa Luxus, reprezentatywna dla nowych poszukiwań bliskich Pomarańczowej Alternatywie. Artyści w atmosferze zabawy na spotkaniach tworzyli art-ziny, rysunki, instalacje i szablony odbijane na domach [Stasiowski 2011: 150-152].

Inspirowana neoekspresjonizmem Gruppa ${ }^{15}$, jedna z najważniejszych formacji artystycznych lat 8o., złożona $\mathrm{z}$ absolwentów warszawskiej ASP, w swojej twórczości nawiązywała do warunków życia społeczeństwa w okresie stanu wojennego. Na przykład prace Włodzimierza Pawlaka z pierwszej połowy dziewiątej dekady w ironiczny sposób komentowały sytuację w kraju. Marek Sobczyk był autorem popularnego w stanie wojennym obrazu Gandzia, przedstawiającego Wojciecha Jaruzelskiego z rakietą w ustach zamiast jointa. Także członkowie krakowskiej grupy Wprost wpisali się w nurt kontestujący poprzez organizację wspólnych wystaw w kościołach. Niektórzy z jej członków intensywnie włączyli się w działalność kultury niezależnej. Jacek Sroka, malarz i grafik, projektował okładki do podziemnych wydawnictw, np. dla ABC, a poznaniak Wojciech Wołyński współpracował z oficynami: warszawską NOW-ą i krakowskim kos-em, przygotowywał też m.in. plakaty dla Teatru Ósmego Dnia. Gdańscy niezależni artyści zaanektowali na przestrzeń ekspozycyjną Wyspę Spichrzów, obszar nad Motławą w centrum miasta. Działała też Galeria Rotacyjna, niezwiązana z jednym miejscem, ale z artystami: Grzegorzem Klamanem i Kazimierzem Kowalczykiem [Kuryłek, Tatar 2011: 175]. Oryginalnym roku, który stwierdzil, że ich poziom artystyczny « nie odbiegał od bełkotu intelektualnego pseudoawangardy»" [Jarecka 2018]. 
przedsięwzięciem warszawskiego plastyka Marka Sapetto było zainicjowanie w 1983 roku niezależnego obiegu malarstwa. Artysta stworzył miniatury, które mieścily się w walizce, i prezentowal je na prywatnych, „objazdowych” wystawach. Inicjatywa przybrała nazwę akcja „Walizka”, a Komitet Kultury Niezależnej uhonorował ją w 1983 roku nagrodą za twórczość artystyczną.

Należy przypomnieć, iż zaangażowanie plastyków w działania kultury niezależnej było wyraźnie widoczne już podczas wydarzeń sierpniowych, kiedy to do strajku przyłączyło się gdańskie Biuro Wystaw Artystycznych, a grafik i ilustrator Jerzy Janiszewski zaprojektował znak graficzny „Solidarność” ${ }^{\prime 16}$. Niebawem zaktywizowali się także artyści fotograficy, którzy obok rzeszy amatorów dokumentowali ludzi oraz ważne wydarzenia tego $\mathrm{czasu}^{17}$.

Kultura niezależna unikała jakiejkolwiek styczności z nurtem podległej kultury oficjalnej. Otwarta była (nie bez zastrzeżeń podnoszonych przez niektórych uczestników i twórców drugiego obiegu) na dialog i współpracę z nurtem kultury konfrontującej, uznawanej za sprzymierzeńca w Sprawie. W podziemnych debatach nad statusem i rolą kultury niezależnej często stawiano tezę o „przejmowaniu czy nieoddawaniu pola kultury". Postulowano sprawiedliwy osąd dorobku kulturowego z tego obszaru. Podczas jednej z dyskusji przeprowadzonej na łamach podziemnego pisma literackiego „Wezwanie” padła znamienna wypowiedź: „Kusi mnie, aby postawić prowokacyjnie może brzmiące pytanie: «czy po stronie oficjalnej» nie powstaje znaczna część tego, co moglibyśmy i powinniśmy zaliczyć do kultury niezależnej?” [B. 1982: 123; cyt. za: Dabert 2014: 102].

W styczniu 1982 roku przy Regionalnej Komisji Wykonawczej (RKW) Regionu Mazowsze powołano do życia Zespół do spraw

Artyści plastycy w czasach jawnej „Solidarności” projektowali tablice pamiątkowe i pomniki upamiętniające protesty społeczne: Czerwca 1956 w Poznaniu, Marca 1968 w Warszawie, Grudnia 1970 w Gdańsku, Gdyni i Szczecinie oraz Czerwca 1976 w Radomiu i Ursusie. Byli autorami licznych plakatów, kartek pocztowych, znaczków, kalendarzy upowszechniających ideały „Solidarności”.

Wśród nich byli m.in.: Tomasz Tomaszewski, Erazm Ciołek, Stanisław Markowski i Chris Niedenthal - autor najsłynniejszego zdjęcia symbolu, przedstawiającego transporter opancerzony stojący przed warszawskim kinem „Moskwa”, na którego fasadzie umieszczony był afisz filmu Czas Apokalipsy Francisa Forda Coppoli. 
Kultury, niebawem przemianowany na Komitet Kultury Niezależnej, który miał wspierać niezależną twórczość kulturalną i naukową. Jednym z ważniejszych zadań Komitetu było doroczne, od 1983 roku aż do końca lat 8o., przyznawanie nagród kulturalnych „za twórczość artystyczną umacniającą ideę ludzkiej solidarności” [Olaszek, wstęp i oprac. 2018: 38$]^{18}$. Jak podkreśla Olaszek: „[... ] doceniano inicjatywy o różnym profilu ideowym”, i co istotne, laureatami byli nie tylko twórcy aktywni w pozacenzuralnym obiegu, ale również ci, którzy tworzyli „w duchu kultury niezależnej” [Olaszek 2017b: 94-95] w przestrzeni oficjalnej i półoficjalnej. Wśród nagrodzonych znaleźli się m.in. filmowcy uhonorowani za reżyserię: Ryszard Bugajski (Przestuchanie), Krzysztof Kieślowski (Przypadek), Janusz Zaorski (Matka Królów), Andrzej Piekutowski (pełnometrażowy film dokumentalny Chłopi 81). Nagrodę otrzymali także aktorzy: Andrzej Szczepkowski za tytułową kreację w sztuce Ambasador Sławomira Mrożka, zrealizowanej w warszawskim Teatrze Dramatycznym, Zbigniew Zapasiewicz za rolę w sztuce Stanisława Bieniasza Eunin, czyli śmiech Kubusia Fatalisty, także wystawionej w Teatrze Dramatycznym. Kazimierza Kutza doceniono za reżyserię spektaklu Stary portfel, zrealizowanego przez Teatr Telewizji. Za swoją twórczość Nagrodę Kulturalną „Solidarności” odebrali również wybitni kompozytorzy polscy: Witold Lutosławski i Wojciech Kilar, a Ryszard Peryt za realizację dzieł scenicznych Wolfganga Amadeusa Mozarta w Warszawskiej Operze Kameralnej. Nagroda trafiła także do historyka Michała Grynberga za opracowanie książki Pamiętniki z getta warszawskiego. Fragmenty i regestry, opublikowanej w Państwowym Wydawnictwie Naukowym.

$\mathrm{Z}$ większym trudem przyjmowano natomiast do wiadomości sens istnienia i ważną pozycję kultury umykającej, zarzucając niekiedy jej uczestnikom nastawienie oportunistyczne. Nierzadko były to oceny niesprawiedliwe [zob. Dabert 2014: 79-104] $]^{19}$.

Konsekwencją całkowitej impregnacji na ideologię komunistyczną było niekiedy odmawianie prawa racji lewicowym ruchom 
wolnościowym, takim jak np. teologia wyzwolenia w Ameryce Łacińskiej ${ }^{20}$, i akceptacja dla niedemokratycznych, antyspołecznych form sprawowania władzy, deklarujących się jednak jako antykomunistyczne. Należy przy tym podkreślić, iż społeczność opozycyjna nie była jednorodna światopoglądowo. Ujawniały to np. profile czasopism preferujących teksty o nachyleniu: konserwatywnym, liberalnym, lewicowym, prawicowym czy nacjonalistycznym.

Wspólnota kultury niezależnej była także niejednolita wiekowo. Co istotne, jej odbiorcami, a zarazem twórcami byli często ludzie bardzo młodzi: studenci, uczniowie, a nawet dzieci. Świadczy o tym, odnotowywana przez wszystkie bibliografie periodyków pozacenzuralnych, znacząca liczba czasopism adresowanych do młodzieży i w dużej mierze przez młodzież redagowanych, a nawet pisemka dla dzieci.

Powstanie dużego ruchu wydawniczego i dystrybucyjnego poza zasięgiem cenzury było ewenementem na skalę światową ${ }^{21}$. Imponujący dorobek drugiego obiegu z lat 1976-1989 szacowany jest na przeszło 6 tys. wydanych tytułów książkowych i przeszło 3,5 tys. tytułów czasopism. Rozpowszechnianie nieocenzurowanej informacji wzmacniane było w latach 80 . przez podziemne stacje radiowe funkcjonujące w kilkudziesięciu miastach i miasteczkach ${ }^{22}$.

Przedstawiciele teologii wyzwolenia, ruchu teologicznego rozpowszechnionego po II soborze watykańskim wewnątrz Kościoła katolickiego w Ameryce Łacińskiej, występowali przeciw dyktaturom, niesprawiedliwości społecznej, bronili praw człowieka w tym rejonie świata. Jan Paweł II oficjalnie potępił ten ruch, stąd konserwatywnie nastawiona opozycja polska odnosiła się do niego równie krytycznie. Na przykład środowisko polityczne skupione wokół krakowskiej „Arki” publikowało na łamach czasopisma teksty potępiające działalność księży i biskupów związanych z teologią wyzwolenia [zob. np. Kłoczowski 1988].

Przyczynił się do tego Jerzy Giedroyć, gdyż zezwolił na przedruki i reprinty publikacji sygnowanych przez Bibliotekę Kultury paryskiego Instytutu Literackiego, a także miesięcznika „Kultura” i „Zeszytów Historycznych”. Większość podziemnych oficyn skwapliwie i w ogromnym zakresie z nich skorzystała. Wśród autorów tych pozycji byli również krajowi twórcy, którzy podjęli ryzyko wykluczenia z obiegu oficjalnego.

Zbigniew Romaszewski, współtwórca warszawskiego Radia „Solidarność” nadającego na falach Radia Wolna Europa, w wyemitowanej 30 kwietnia 1982 roku audycji podkreślił konsolidacyjny charakter przedsięwzięcia: „Chcemy, aby z naszą radiostacją mogli identyfikować się wszyscy, którzy tworzą ponad 10-milionowy ruch Solidarność” [cyt. za: Podziemne Radio „Solidarnośc”... 2021]. 
Jak słusznie przypomina Olaszek:

wokół drugiego obiegu formował się cały ruch społeczny. Równie ważny co treść nieocenzurowanych publikacji był sam fakt ich istnienia. W niezależnym ruchu wydawniczym miejsce dla siebie znalazł każdy, kto był gotów do działania. [Olaszek 2015: 334]

Nie dziwi więc, że przegląd publikacji drugiego obiegu wydawniczego ujawnia zróżnicowanie ich jakości merytorycznych i artystycznych. Dziełom wybitnym towarzyszyły słabsze, mierne, na granicy kiczu lub ją przekraczające.

Objaśnienia wymaga także sama nazwa drugi obieg, która pojawiła się jeszcze pod koniec lat 70. we wrogo nastawionej publicystyce oficjalnej. W pewnym momencie została przejęta przez użytkowników i twórców działających poza zasięgiem cenzury. Termin jest jednak mylący, bowiem odnosi się do modeli socjologicznych kultury wydzielających różne jej obiegi. Jednak w moim przekonaniu powinien zostać utrzymany z jednego, ale istotnego powodu. Fenomen drugiego obiegu nie może być utożsamiany ze zjawiskiem samizdatu występującym w innych krajach bloku wschodniego. W Polsce faza samizdatu była jedynie wstępnym etapem rozwoju publikacji niecenzurowanych, który jeszcze przed Sierpniem 1980 roku począł przeobrażać się w nową jakość. Nie chodzi tu tylko o techniczno-formalne różnice dzielące publikacje samizdatowe i drugoobiegowe. Należy pamiętać o nieporównywalnym zasięgu obu tych zjawisk. Ta niewspółmierność powinna być zaznaczona w nazwie, by nie dokonano - a próby takie się pojawiają - zrównania polskiego fenomenu $\mathrm{z}$ kulturą samizdatu występującą w ZSRR, Czechosłowacji czy na Węgrzech, a w szczątkowych formach również w innych państwach komunistycznych.

Ogromną zasługą drugiego obiegu wydawniczego było systematyczne i prowadzone na wielką skalę przybliżanie dorobku kultury polskiej powstałej w rozproszeniu na świecie. W latach 8o. literatura emigracyjna płynęła już do kraju szerokim nurtem, a na kształt i jakość podziemnego ruchu wydawniczego ogromny wpływ miała działalność emigracyjnych ośrodków kultury. Pierw- 
szorzędną rolę odegrał Instytut Literacki w Paryżu kierowany przez Jerzego Giedroycia. Wydawane nakładem IL publikacje: książki oraz numery miesięcznika „Kultura” w formie reprintów i niezliczonych przedruków zasiliły ofertę wydawniczą wielu oficyn podziemnych. Ponadto ośrodek stał się mecenasem dla niezależnych wydawców krajowych. Według ustaleń Marcina Łaszczyńskiego:

Jednym z najważniejszych ośrodków wspierających niezależną kulturę w Polsce był Instytut Literacki w Paryżu, który m.in. wspierał finansowo pisarzy, tłumaczy i wydawców podziemnych. Pomoc dotyczyła zarówno dotacji kierunkowych na konkretny tytul, jak i stałych stypendiów ${ }^{23}$.

Rozważając fenomen kultury niezależnej, nie można pominąć kulturo- i opiniotwórczej roli rozgłośni polskich na Zachodzie, a zwłaszcza polskiej sekcji Radia Wolna Europa, która emitowała audycje poświęcone kulturze krajowej i emigracyjnej. Rozgłośnia od 1952 roku nieprzerwanie i systematycznie przekazywała informacje o wszelkich przejawach kultury kontestującej w Polsce, prezentowała literaturę zakazanych w kraju autorów [zob. Tatarowski 2005]. To dzięki niej, zanim jeszcze powstał drugi obieg, do kraju docierały informacje dotyczące kultury polskiej rozwijającej się na emigracji i niezakłamane relacje o dokonaniach krajowych. Radio przyczyniło się do zbudowania nawyku krytycznego odbioru informacji przez obywateli, umożliwiło konfrontowanie monolitycznego przekazu płynącego z państwowych mediów z alternatywnym obrazem rzeczywistości, który oferowała rozgłośnia. Radiowy przekaz trafiał do nieporównywalnie większego kręgu odbiorców niż publikacje drugiego obiegu. Wieloletni dyrektor RWE Jan Nowak-Jeziorański tak widział rolę rozgłośni w upowszechnianiu niezależnej myśli i kultury w Polsce:

„Minimalna dotacja przekazywana przez «Kulturę», na przykład miesięczne stypendium dla jednej osoby w kraju, wynosiła 30-50 dolarów. Organizacje i wydawnictwa otrzymywały od 1 tys. do 5 tys. dolarów jednorazowo lub 5001000 dolarów miesięcznie. W 1987 r. jeden dolar na czarnym rynku w Polsce kosztował tysiąc zł, a średnia pensja nauczyciela akademickiego wynosiła 15 tys. zł" [Łaszczyński 2010: 152]. 
[po strajkach w Radomiu i Ursusie - D.D.] istniała już nie tylko opozycja wewnętrzna, ale także niezależna prasa i RWE stało się komunikacyjnym pasem transmisyjnym, który umożliwiał nagłaśnianie opozycji, szerzenie głosu prasy niezależnej i informowanie kraju o tym, co dzieje się w jakimś jego zakątku. [Nowak-Jeziorański 2003: 32]

Od lat 70., niejako równolegle $\mathrm{z}$ dynamicznie rozwijającym się drugim obiegiem, ujawniło się zjawisko jeszcze wtedy mało widoczne i niedoceniane, jakim był trzeci obieg kultury ${ }^{24}$, sytuujący się poza obiegami oficjalnym i drugim. Jego uczestnikami byli przedstawiciele pokolenia młodszego niż opozycjoniści z lat 70. i 80. Trzeci obieg był zjawiskiem wyrażającym dystans zarówno wobec formacji opozycyjnych, jak i oficjalnych, wyraźnie jednak akcentującym negatywny stosunek do władzy.

Źródłem tradycji były ruchy alternatywne, kontrkulturowe, a w centrum zainteresowania znalazła się muzyka zrodzona na tym gruncie. Jak podkreśla Katarzyna Bielska [2020: 196], autorka pracy poświęconej trzeciemu obiegowi: „[...] od drugiego obiegu odróżniał się nie tylko środkami wyrazu, ale również tym, że wytwory te nie były wyraźnym postulatem politycznym". W początkowej fazie, do 1980 roku, twórcy trzeciego obiegu, dostrzegając w drugim obiegu postawy anarchizujące, zbliżyli się do kultury opozycyjnej, jednak po 1981 roku ich drogi się rozeszły. Wówczas twórcy trzeciego obiegu rozpoznali i zdefiniowali własną tożsamość. Zdystansowali się wyraźnie od otaczającej ich rzeczywistości, tej politycznej, ekonomicznej i społecznej. Pisma przez nich wydawane, określone mianem zinów, artzinów i funzinów, dotyczyły muzyki alternatywnej, problematyki ekologicznej, wegetariańskiej czy filozoficznej, i wypełniały przestrzeń tematyczną $\mathrm{w}$ zasadzie nieobecną $\mathrm{w}$ drugim obiegu. Podsumowując swoje rozważania, Bielska zwróciła uwagę na specyfikę fenomenu trzeciego obiegu, nie tyle zaprzeczającego wartościom drugiego obiegu, ile wypełniającego niezagospodarowane przestrzenie dyskursu kulturowego w Polsce: 
Kontrkultura łamała przyjęty ład społeczny, konwenanse kultury wiodącej, desygnatem czego była nie tylko tematyka tekstów, ale również dobór słów. Język ten był często w dużej mierze niezrozumiały dla starszego pokolenia, bezkompromisowy, dosadny, autorzy nie unikali wulgaryzmów. Odzwierciedlało to również przemiany kulturowo-społeczne, jakich młode pokolenie doświadczało najbardziej. Twórcy zinów byli przedstawicielami grupy rozgoryczonej i rozczarowanej nie tylko władzą, ale ogólnym marazmem w kraju. Mając nieco większe możliwości niż starsze pokolenie poznawali wciąż niedostępny demokratyczny świat Zachodu. [Bielska 2020: 198]

W latach 8o. happeningowy ruch Pomarańczowej Alternatywy, obecny na ulicach kilku polskich miast jako spontaniczna i przede wszystkim wspólnotowa forma protestu ulicznego, wytwarzał nowe enklawy wolności. Nie tylko przełamywał strach przed represyjnym systemem, lecz także karnawalizował rzeczywistość, zawieszając obowiązujący system znaczeń do tej pory porządkujący relacje władza - społeczeństwo. Równie niebagatelną rolę odegrał krakowski kwartalnik literacki „Brulion”. Czasopismo, którego pierwszy numer ukazał się w 1987 roku, początkowo zaskoczyło nową artystyczną strategią opartą na zderzaniu utworów z kanonu literatury podziemnej z tekstami kabaretowymi, poświęconymi muzyce rockowej, czy z obyczajowo skandalizującym pisarstwem, np. Georges’a Bataille'a. Podważało nie tylko obowiązujące w drugim obiegu normy kulturowo-obyczajowe, lecz także jednocześnie dychotomiczny układ kultury oficjalnej i nieoficjalnej.

W Polsce, pomimo ograniczeń spowodowanych funkcjonowaniem w warunkach nieustannej niepewności i lęku przed represjami, zaistniała imponująca różnorodność form i inicjatyw kultury niezależnej. W końcowych latach trwania PRL udało się nawet, przezwyciężywszy ograniczenia nie tylko polityczne, lecz także techniczne, uruchomić produkcję i dystrybucję niezależnego filmu [zob. Nowakowski 2019]. 
Spojrzenie na tak zarysowaną mapę polskiej kultury w warunkach realiów pojałtańskich pozwala zbudować pewne hipotezy wyjaśniające specyfikę zjawiska określanego mianem kultury niezależnej. Wyraźnie widać, iż nie można jej sprowadzać jedynie do nurtu kultury pozacenzuralnej, bogatej i wewnętrznie zróżnicowanej, która była najbardziej radykalną postawą publicznej kontestacji. Jakkolwiek od 1976 roku polski drugi obieg był największym tego typu przedsięwzięciem w krajach znajdujących się pod wpływem wschodniego Imperium, to jednak nie stanowił, bo stanowić nie mógł, pełnej alternatywy dla życia artystycznego, naukowego i duchowego rozwijającego się w ramach kurateli państwowej. Bez wątpliwości można stwierdzić, iż nie byłoby drugiego obiegu bez tych postaw i aktywności, które ujawniły się w ramach kultury oficjalnej i opatrzone zostały tu określeniami oficjalnej kultury umykającej ograniczeniom, tej idącej na konfrontację i niszowej. Tak rozumiana kultura niezależna nie była w żadnym razie zjawiskiem elitarnym. Wieloletni wysiłek wyszukiwania alternatywnych dróg wyjścia poza jednowymiarowość kultury oficjalnej, wykorzystywanie wszystkich szczelin w jej monolicie zaowocował ocaleniem najistotniejszych wartości intelektualnych i artystycznych, a w rezultacie zapewnieniem ciągłości tożsamościowej kultury polskiej.

\section{Bibliografia}

B. [uczestnik dyskusji] (1982), Granica jest nakreślona. Dyskusja w redakcji, „Wezwanie”, nr 2/3, s. 119-124.

Barańczak Stanisław (1974), Język poetycki Białoszewskiego, Ossolineum, Warszawa.

Barańczak Stanisław (1981), Fasada i tyły, w: tegoż, Etyka i poetyka. Szkice 1970-1978, ABC, Kraków [przedruk: Instytut Literacki, Paryż 1979, s. 253-259].

Bauer Zbigniew (1980), Telefon do rzeczywistości, „Życie Literackie”, nr 42, s. 6.

Bielska Katarzyna (2020), Trzeci obieg wydawniczy w PRL oraz drugi obieg w latach 70. $i$ 8o., [dostęp: 3 maja 2020], https://tinyurl.com/42fmjtmx, s. 194-201.

Bittner Karolina (2017), Partia z piosenka, piosenka z Partią. PZPR wobec muzyki rozrywkowej, IPN, Warszawa. 
Błoński Jan (1990), Bezładne rozważania starego krytyka, który zastanawia się, jak napisałby historię prozy polskiej w latach istnienia Polski Ludowej, „Teksty Drugie”, nr 1, s. 5-24.

Bugajski Leszek (1980), W środku, „Polityka”, nr 46, s. 10.

Cieśliński Marek Kosma (2016), Polska Kronika Filmowa. Podglądanie PRL- $u$, Bosz, Warszawa.

Czapliński Przemysław (2006), Dziedzictwo niezależności. Krótka historia komunikacyjnego podziemia, w: „Literatura II obiegu w Polsce w latach 1976-1989". Ogólnopolska konferencja. Materiały konferencyjne, red. Leszek Laskowski, Koszalińska Biblioteka Publiczna im. Joachima Lelewela, Koszalin, s. 5-26.

Dabert Dobrochna (2014), Między wizją a spetnieniem. Profile ideowe $i$ artystyczne czasopism literackich $w$ drugim obiegu wydawniczym 1982-1989, Wydawnictwo Naukowe UAM, Poznań.

Dunin-Wąsowicz Paweł, Varga Krzysztof, red. (1995), Parnas Bis [słownik literatury polskiej urodzonej po 1960 roku], Odeon, Warszawa.

Eisler Jerzy, Terlecki Ryszard (2002), O kulturze w PRL. Z Jerzym Eislerem i Ryszardem Terleckim rozmawia Barbara Polak, „Biuletyn IPN”, nr 10, s. 5-23, [dostęp: 12 grudnia 2017], https://tinyurl.com/26tb3re9.

Friszke Andrzej (2018), Ucieczka od wolności. Rozmowa z prof. Andrzejem Friszke Aleksandry Pawlickiej, „Newsweek”, nr 33, s. 18-23.

Głowiński Michał (1981), Socparnasizm, „Polityka”, nr 6, s. 11.

Głowiński Michał (1992), Socparnasizm, w: tegoż, Rytuat i demagogia.

Trzynaście szkiców o sztuce zdegradowanej, Open, Warszawa, s. 157-161.

Głowiński Michał (2002), Ornitolog w ptaka przemieniony, w: Piotr Szewc i in., Wolność $i$ wspótczucie. Rozmowy z pisarzami, Wydawnictwo Literackie, Kraków, s. 21-36.

Jarecka Dorota (2018), Janusz Bogucki, Polski Szeemann?, [dostęp: 17 czerwca 2018], https://tinyurl.com/ecznb3c7.

Kelus Jan Krzysztof (1981), Piosenka patetyczna, w: tegoż, Dowód osobisty. Piosenki z lat 1968-1981 (Do śpiewania wewnętrznego), Grot, Warszawa, s. 60.

Kłoczowski Jan A. (1988), Teologia wyzwolenia. Z dominikaninem Janem A. Kłoczowskim rozmawia Ryszard Legutko, „Arka”, nr 23, s. 61-66.

Kościuczuk Krzysztof (2016), W polu „oficjalnej kultury” PRL. Rozmowa z Krzysztofem Kościuczukiem, „Szum”, 28 września, [dostęp: 23 marca 2018], https://tinyurl.com/3cpk275w.

Krzemiński Adam (1980), Między fasadą a tyłami, „Polityka”, nr 40, s. 1 i 7. Kulerski Wiktor (2018), Społeczeństwo podziemne, czyli „Solidarnośc” przeciwko totalitaryzmowi [XI 1984. Międzynarodowe sympozjum 
Polska - społeczeństwo niezależne, Turyn 25-26 I 1985], w: Archiwum Wiktora Kulerskiego. Dokumenty podziemnej „Solidarności” 1982-1986, wstęp i oprac. Jan Olaszek, posłowie Andrzej Friszke, IPN, Warszawa, s. 744-747.

Kuryłek Dominik, Tatar Ewa Małgorzata (2011), „Tu jest teraz”. Artyści i gdańska Wyspa Spichrzów, w: Odrzucone dziedzictwo, Muzeum Sztuki Nowoczesnej, Warszawa, s. 174-187.

Lubelski Tadeusz (2015), Historia kina polskiego 1895-2014, Universitas, Kraków.

Łaszczyński Marcin (2010), „Krą" i jego krąg. Wydawnictwo w świetle relacji, „Pamięć i Sprawiedliwość”, nr 9/2, s. 139-169.

Morawiec Elżbieta (1980), Refleksje o rozdwojonej jaźni, „Życie Literackie", nr 42, s. 6.

Nowakowski Jacek (2019), W poszukiwaniu niezależności w filmie i kulturze okresu PRL. Szkice, Wydawnictwo Naukowe UAM, Poznań.

Nowak-Jeziorański Jan (2003), Polska z bliska, Znak, Kraków.

Nycz Ryszard (1998), Literatura polska w cieniu cenzury: wykład, „Teksty Drugie", nr 3, s. 5-27.

Olaszek Jan (2015), Rewolucja powielaczy. Niezależny ruch wydawniczy $w$ Polsce 1976-1989, Trzecia Strona, Warszawa.

Olaszek Jan (2017a), Kultura, która nie kłamie. Szkic o Komitecie Kultury Niezależnej, „Wolność i Solidarność”, nr 10, s. 82-116.

Olaszek Jan (2017b), Od opozycji do Bednarskiej, w: tegoż, Przeciw PRL. Szkice z dziejów opozycji demokratycznej, Znak, Warszawa, s. 167-180.

Olaszek Jan, wstęp i oprac. (2018), Archiwum Wiktora Kulerskiego.

Dokumenty podziemnej „Solidarności” 1982-1986, posłowie Andrzej Friszke, IPN, Warszawa.

Oświadczenie programowe TKK NSZZ „Solidarność” „Solidarność $d z i s s^{\prime \prime}[\mathrm{z}$ dnia 22 stycznia 1983] (2010), w: Dokumenty wtadz NSZZ „Solidarność”, wstęp i oprac. Jan Olaszek, IPN, Warszawa, s. 103-110, [pierwodruk: „Tygodnik Mazowsze” 1983, nr 41 (27 stycznia)].

Paczkowski Andrzej (1995), Pót wieku dziejów Polski. 1939-1989, PWN, Warszawa.

Pęczak Mirosław (1988a), Kilka uwag o trzech obiegach, „Więź”, nr 2, S. 25-35.

Pęczak Mirosław (1988b), O wybranych formach komunikowania alternatywnego w Polsce, „Kultura i Społeczeństwo”, nr 3, s. 167-182.

Pęczak Mirosław (1992), Mały słownik subkultur młodzieżowych, Semper, Warszawa.

Podziemne Radio „Solidarność” 1982-1989 (2021), [dostęp: 7 marca 2021], https://tinyurl.com/em6zxska. 
„Polaków portret wtasny” dziś (2018), [dostęp: 12 lipca 2018], https:// tinyurl.com/uur4cmvf.

Rem Jan [właśc. Jerzy Urban] (1986), Tydzień pełen zgrzytów, „Gazeta Krakowska" nr 4, s. 1 i 4.

Sadurski Wojciech (1980), Sfery pośrednie, „Polityka”, nr 44, s. 8.

Saloni Zygmunt (1987), Uwagi o organizacji prac nad Wielkim stownikiem wspótczesnego języka polskiego i ich obstudze komputerowej, w: Studia z polskiej leksykografii wspótczesnej, t. 2, red. Zygmunt Saloni, Dział Wydawnictw Filii uw, Białystok, s. 344-345.

Sobolewski Tadeusz (2012), Kino swoimi stowami, Universitas, Kraków. Stasiowski Piotr (2011), Doświadczenia niezależności wrocławskiego środowiska w latach 8o., w: Odrzucone dziedzictwo, Muzeum Sztuki Nowoczesnej, Warszawa, s. 148-159.

Szaruga Leszek (1980), Zza fasady, „Polityka”, nr 46, s. 10.

Szczerba Jacek (2015), Maj, czyli Bond, „Ale Historia”, dodatek do: „Gazeta Wyborcza”, 4-6 kwietnia, s. 14-15.

Szkiłądź Hipolit (1997), Redakcja "Stowników Języka Polskiego”, w: Halina Auderska, Maria Borowska i in., Alfabet PwN. Ludzie, książki, lata, wspomnienia, PWN, Warszawa, s. 326-336.

Ściegienna Aleksandra (2011), Ankieta Stowarzyszenia Historyków Sztuki „Artyści-Plastycy 84-86”, w: Odrzucone dziedzictwo. O sztuce polskiej lat 8o, Muzeum Sztuki Nowoczesnej, Warszawa, s. 70-84.

Tatarowski Konrad (2005), Literatura i pisarze w programie Rozgłośni Polskiej Radia Wolna Europa, Universitas, Kraków.

Toborek Tomasz (2010), Niezależna muzyka rockowa, IPN, Łódź. Werner Andrzej (1980), Kość niezgody, „Polityka”, nr 44, s. 8.

Wierzbicki Piotr (1980), Między nazwiskami a treścia, „Tygodnik Powszechny", nr 43, s. 8.

Wstępne założenia deklaracji programowej Tymczasowej Komisji Koordynacyjnej „Społeczeństwo podziemne” (2010), w: Dokumenty władz NSZZ „Solidarność", wstęp i oprac. Jan Olaszek, IPN, Warszawa, s. 72-75, [pierwodruk: „Tygodnik Mazowsze” 1982, nr 22 (28 lipca)]. Zakrzewska Janina (1980), Gdzie te ksią̇ki, „Polityka”, nr 48, s. 10. Ziemny Aleksander (1980), Głowy w bunkrach, „Polityka”, nr 48, s. 10.

Dobrochna Dabert

Alternatives to One-Dimensionality. The Phenomenon of Polish Independent Culture in Polish People's Republic

In this article devoted to the independent culture in Polish People's Republic, I put into dichotomic doubt the concept based on the clear division 
between the official and independent culture. The forms of creative activity that escaped the state censorship between 1976 and 1989 radically disrespected the directives of the state's cultural policy, yet many years before the emergence of 'the second circulation', there were already numerous initiatives that sparked a rich spectrum of independent activity. The authors' strategies to remain independent changed over time, to varying extent distanced the authors from the official artistic life and differed depending on the character of the authors' intellectual activity. In the article, I attempt to prove the relatively weak influence of the 'official dependent culture' that fully respected the authorities' instructions, and I propose a classification of creative strategies that also emerged in the official culture and allowed for a relatively free development of art and science. Using multiple examples from literature, cinema, visual arts, music and science, I discuss 'controlled culture escaping the ideological instructions', 'official niche culture', 'culture confronting the limitations', 'licensed Catholic culture', 'second circulation culture' and 'third circulation culture.' The practice of searching for a way out of the official one-dimensionality allowed Polish cultural identity to continue and save its most valuable intellectual and artistic values.

Keywords independent culture; official culture; Polish People's Republic; 'second circulation of publications'.

Dobrochna Dabert - profesor UAM doktor habilitowana, filmoznawca i literaturoznawca. Pracuje w Instytucie Filologii Polskiej, kieruje Pracownią Badań Literatury i Kultury Niezależnej. Autorka książek: Zbuntowane wiersze. O języku poezji stanu wojennego (1998), Kino moralnego niepokoju. Wokót wybranych zagadnień z poetyki i etyki (2003), Mowa kontrolowana. Szkice o języku publicznym w Polsce po 1989 roku (2003), Między wizją a spetnieniem. Profile ideowe i artystyczne czasopism literackich $w$ drugim obiegu wydawniczym 1982-1989 (2014). Adres e-mail: dobro@amu.edu.pl. 